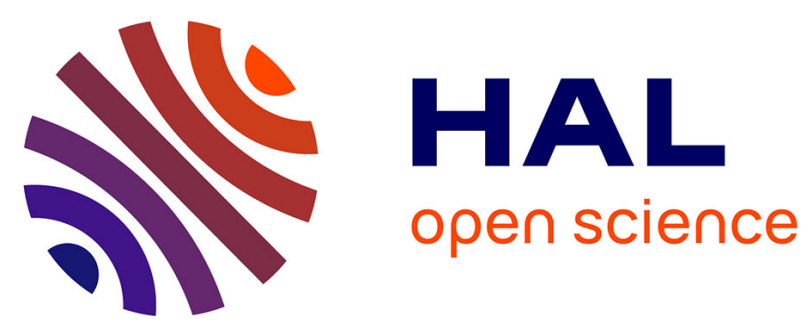

\title{
Multilocus sequence typing of Propionibacterium freudenreichii
}

Marion Dalmasso, Pierre Nicolas, Hélène Falentin, Florence Valence, Jarna

Tanskanen, Hanna Jatila, Tuomas Salusjärvi, Anne Thierry

\section{To cite this version:}

Marion Dalmasso, Pierre Nicolas, Hélène Falentin, Florence Valence, Jarna Tanskanen, et al.. Multilocus sequence typing of Propionibacterium freudenreichii. International Journal of Food Microbiology, 2011, 145 (1), pp.113-120. 10.1016/j.ijfoodmicro.2010.11.037 . hal-01454161

\section{HAL Id: hal-01454161 \\ https://hal.science/hal-01454161}

Submitted on 28 May 2020

HAL is a multi-disciplinary open access archive for the deposit and dissemination of scientific research documents, whether they are published or not. The documents may come from teaching and research institutions in France or abroad, or from public or private research centers.
L'archive ouverte pluridisciplinaire HAL, est destinée au dépôt et à la diffusion de documents scientifiques de niveau recherche, publiés ou non, émanant des établissements d'enseignement et de recherche français ou étrangers, des laboratoires publics ou privés. 


\title{
Multilocus sequence typing of Propionibacterium freudenreichii
}

\author{
Marion Dalmasso $^{\mathrm{a}, \mathrm{b}, 1}$, Pierre Nicolas ${ }^{\mathrm{c}, 1}$, Hélène Falentin ${ }^{\mathrm{a}, \mathrm{b}}$, Florence Valence ${ }^{\mathrm{b}, \mathrm{d}}$, Jarna Tanskanen ${ }^{\mathrm{e}}$, \\ Hanna Jatila ${ }^{\mathrm{e}}$, Tuomas Salusjärvi ${ }^{\mathrm{e}}$, Anne Thierry ${ }^{\mathrm{a}, \mathrm{b}, *}$ \\ a INRA, UMR1253 Science et Technologie du Lait et de l'EFuf, F-35042 Rennes, France \\ ${ }^{\mathrm{b}}$ AGROCAMPUS OUEST, UMR1253 Science et Technologie du Lait et de l'Euf, F-35042 Rennes, France \\ c INRA, UR1077 Mathématique Informatique et Génome, F-78350 Jouy-en-Josas, France \\ d CIRM-BIA, INRA, UMR1253 Science et Technologie du Lait et de l'Euf, F-35042 Rennes, France \\ e Valio Ltd, PO Box 30, FI-00039 VALIO, Helsinki, Finland
}

\section{A R T I C L E I N F O}

\section{Article history:}

Received 31 August 2010

Received in revised form 24 November 2010

Accepted 25 November 2010

Available online 1 December 2010

\section{Keywords:}

Multilocus sequence typing

Propionibacterium freudenreichii

Recombination

Mutation

Subspecies

\begin{abstract}
A B S T R A C T
Propionibacterium freudenreichii is used as a ripening culture in Swiss cheese manufacture. This study investigates the molecular diversity and the population structure of this bacterium via multilocus sequence typing (MLST). Internal fragments of seven genes sequenced for 113 strains of different subspecies and origins allowed the resolution of 46 sequence types (STs) with occurrence frequencies ranging from 1 to 11 . The core genome of the species harbours a low level of nucleotide polymorphism. In our data, single nucleotide polymorphisms account for only $2.28 \%$ of the concatenated sequences, and the average polymorphism rate in pairwise comparisons is $0.46 \%$. The analyses reveal quantitatively comparable contributions of recombination and mutation in nucleotide changes at core genome loci along cell lineages. Remarkably, the STs exhibit little if any dairy biotope specialization. Phenotypic characterisation of the strains, based on their aptitude to use lactose and nitrate, shows that the two previously identified subspecies (freudenreichii and shermani) do not reflect the ancestral relationships in the $P$. freudenreichii population. The considerable phenotypic heterogeneity, found even at the ST level, suggests instead a history of recurrent switches between phenotypes.
\end{abstract}

(c) 2010 Elsevier B.V. All rights reserved.

\section{Introduction}

Propionibacterium freudenreichii belongs to the dairy group of propionic acid bacteria included in the Actinobacteria class of high $\mathrm{G}+\mathrm{C}$ content Gram-positive bacteria. The species has mostly been isolated from dairy products and especially from Swiss cheese in which its population density generally reaches $10^{9}$ colony-forming units (cfu)/g. By converting lactic acid into propionic and acetic acids and $\mathrm{CO}_{2}$, it is the main bacterium involved in the holes and flavor formations in Swiss-type cheeses, like Emmental and Leerdammer $`$ cheeses (Langsrud and Reinbold, 1973). It also contributes to the formation of other aroma compounds in cheese thanks to the conversion of branched-chain amino acids into short branched-chain fatty acids, and to the hydrolysis of milk fat to free fatty acids (Dherbécourt et al., 2010; Thierry et al., 2002; Thierry et al., 2005). A growing attention is paid to the probiotic potential of $P$. freudenreichii such as modulation of the microbiota, enzymatic activities, immune system, inflammation and carcinogenesis, at the gut level (Cousin et al., 2010; Jan et al., 2007). P. freudenreichii is divided into

\footnotetext{
* Corresponding author. Mailing address: INRA, AGROCAMPUS OUEST, UMR1253 Science et Technologie du Lait et de l'Euf, 65 rue de Saint-Brieuc, F-35042 Rennes cedex, France. Tel.: +332234853 37; fax: +33223485350.

E-mail address: anne.thierry@rennes.inra.fr (A. Thierry).

${ }^{1}$ Marion Dalmasso and Pierre Nicolas contributed equally to the manuscript.
}

two subspecies, P. freudenreichii subsp. freudenreichii and $P$. freudenreichii subsp. shermanii, on the basis of lactose fermentation and nitrate reductase activity (Cummins and Johnson, 1986). Many P. freudenreichii activities are strain-dependant, like its survival and metabolic activity in the digestive tract (Lan et al., 2007), its autolytic activity (Lemée et al., 1995) and its production of aroma compounds (Dherbécourt et al., 2008; Thierry et al., 2005). Despite this diversity of reported phenotypes, there is a lack of information concerning the molecular diversity in the species and the relationships between strains that could define its population structure. The few data concerning the molecular diversity of propionibacteria strains are based on fingerprinting characterizations such as Randomly Amplified Polymorphic DNA (RAPD)-PCR and Pulsed-Field Gel Electrophoresis (PFGE) (Gautier et al., 1996; Rehberger, 1993; Rossi et al., 1998). These methods have proven to be useful for the identification of Propionibacterium strains in some cases. Nevertheless, RAPD-PCR and PFGE remain clustering techniques that hardly provide information about $P$. freudenreichii nucleotide diversity and mode of evolution.

Multilocus sequence typing (MLST), a method based on partial nucleotide sequences of multiple genes, has emerged as an alternative typing tool to study bacterial populations. It is recognized for its high degree of resolution and its capacity to rapidly characterize large numbers of isolates (Maiden et al., 1998). As MLST is based on DNA sequence analysis, it allows a phylogenetic approach of bacterial population that other typing tools do not permit. Therefore, it has 
been largely used for epidemiologic and phylogenetic studies of pathogenic bacteria such as Neisseria (Hanage et al., 2005) or Staphylococcus aureus (Sakwinska et al., 2009). MLST has more recently been applied to bacteria used in the food industry like Oenococcus oeni (de Las Rivas et al., 2004), Lactobacillus casei (Cai et al., 2007), Lactobacillus plantarum (de las Rivas et al., 2006), and Streptococcus thermophilus (Delorme et al., 2010).

The present study was undertaken to investigate the population structure of $P$. freudenreichii by means of the first MLST scheme developed for a member of the Propionibacterium genus. The results of our analysis indicate that the core genome of $P$. freudenreichii displays a low level of nucleotide diversity and undergoes frequent recombination events, both characteristics contributing to the species cohesiveness. Our results also show that the lineages of recent common ancestry as defined by the sequence types exhibit broad dairy biotope ranges and phenotypic diversity.

\section{Materials and methods}

\subsection{Bacterial strains, growth conditions and DNA extractions}

A total of 113 P. freudenreichii strains from CIRM-BIA (Centre International de Ressources Microbiennes - Bactéries d'Intérêt Alimentaire, INRA, Rennes, France), Valio Ltd (Helsinki, Finland) and Actilait (Institut technique du lait et des produits laitiers, Rennes, France) collections were used (Table 1). Their origin is representative of the main biotopes where $P$. freudenreichii strains have been isolated so far: Swiss cheeses ( 58 strains), other cheeses ( 25 strains), milk (17 strains), other biotopes (5 strains) and unknown origin (8 strains). Strains originated from ten countries, the best represented being Finland (57 strains) and France (36 strains).

All the strains were routinely cultured in YEL broth (Malik et al., 1968) at $30^{\circ} \mathrm{C}$ under microaerophilic conditions for $48 \mathrm{~h}$. Cells were harvested from $2 \mathrm{ml}$ of each culture $(8000 \mathrm{~g}, 10 \mathrm{~min}$, ambient temperature), suspended in $180 \mu \mathrm{l}$ lysis buffer (lysozyme $20 \mathrm{mg} / \mathrm{ml}$, mutanolysin $50 \mathrm{U} / \mathrm{ml}$ in $20 \mathrm{mM}$ Tris- $\mathrm{HCl}$ [pH 8], $2 \mathrm{mM}$ EDTA and 1\% $(\mathrm{v} / \mathrm{v})$ Triton $\mathrm{X} 100)$, and incubated for $1 \mathrm{~h}$ at $37^{\circ} \mathrm{C}$. DNA was then extracted by means of DNeasy tissues kit (QIAGEN, Courtaboeuf, France).

\subsection{Subspecies characterization}

All the strains were tested for the presence of a nitrate reductase activity and for lactose fermentation. Nitrate reductase activity was detected by means of the Griess reagent (Biomérieux, Marcy l'Etoile, France) after strain incubation on broth containing nitrate (potassium nitrate $1.5 \mathrm{~g} / \mathrm{l}$ (VWR International, Fontenay-sous-Bois, France), tryptone $10 \mathrm{~g} / \mathrm{l}$, yeast extract $5 \mathrm{~g} / \mathrm{l}$, glucose $1 \mathrm{~g} / \mathrm{l}$ ) for $48 \mathrm{~h}$ at $30^{\circ} \mathrm{C}$ under microaerophilic conditions. Lactose fermentation was tested on modified API 50CH media (tryptone $10 \mathrm{~g} / \mathrm{l}$, yeast extract $5 \mathrm{~g} / \mathrm{l}, \mathrm{K}_{2} \mathrm{HPO}_{4}$ $0.25 \mathrm{~g} / \mathrm{l}, \mathrm{MnSO}_{4} 0.05 \mathrm{~g} / \mathrm{l}$, and bromocresol purple $0.17 \mathrm{~g} / \mathrm{l}$ ). One milliliter of a lactose solution ( $200 \mathrm{~g} / \mathrm{l}$, Panreac, Lyon, France) was added to $9 \mathrm{ml}$ of modified API 50CH medium. Strains were incubated at $30^{\circ} \mathrm{C}$ for $48 \mathrm{~h}$ under microaerophilic conditions. All the tests were carried out in triplicate.

\subsection{Loci, primers, PCR conditions and sequencing}

The genome sequence of the type strain $P$. freudenreichii CIRM-BIA1 ${ }^{\mathrm{T}}$ $\left(\mathrm{CIP} 103027^{\mathrm{T}}\right.$ ) (Falentin et al., 2010) was used for choosing the genes encoding the following proteins: RNA polymerase $\beta$-subunit (rpoB), adenylate kinase ( $a d k)$, carboxylic ester hydrolases ( $p f 169$ and pf1637), DNA recombinase A (recA), fumarate hydratase (fumC), cell-wall polysaccharide synthase $(g t f)$. Primers were designed with Primer3Plus software (Untergasser et al., 2007) and their sequences are specified in Table 2. PCR reactions were performed in $50 \mu$ containing Taq DNA polymerase buffer (100 mM Tris- $\mathrm{HCl}$ [pH 8.8], $500 \mathrm{mM} \mathrm{KCl,} 0.8 \%$ Nonidet P40), $2 \mathrm{mM} \mathrm{MgCl} 2,200 \mu \mathrm{M}$ of dNTPs, $0.5 \mu \mathrm{M}$ of each primer, $0.5 \mathrm{U}$ Taq DNA polymerase (Fermentas, Saint-Rémy-Les-Chevreuses, France) and $2 \mu \mathrm{l}$ of template DNA (equivalent to 20-50 ng). The PCR amplifications were carried out with an initial denaturation step at $95^{\circ} \mathrm{C}$ for $3 \mathrm{~min}$, followed by 40 cycles of denaturation at $95^{\circ} \mathrm{C}$ for $30 \mathrm{~s}$, annealing for $30 \mathrm{~s}$ at the appropriate primer set temperature (Table 2) and extension at $72{ }^{\circ} \mathrm{C}$ for $30 \mathrm{~s}$; and ending with $72{ }^{\circ} \mathrm{C}$ for $10 \mathrm{~min}$. For each PCR product, both forward and reverse DNA strands were sequenced using the same primers as for PCR by the sequencing service of AGOWA genomics (Berlin, Germany).

\subsection{Description of the sequence polymorphism}

Each distinct gene sequence was arbitrarily assigned an allele number or allele type (AT) and each unique combination of the seven gene ATs was assigned a sequence type (ST) (Maiden, 2006). The mean $\mathrm{G}+\mathrm{C}$ content at the seven loci was calculated. The detection of intra- and inter-loci recombination events and the minimal number of homoplasies were respectively assessed by means of the statistics $R_{\min }$ and $h$ using LDhat and DNApars (PHYLIP) (Nicolas et al., 2008). $R_{\min }$ is the Hudson and Kaplan's lower bound on the minimal number of recombination events needed to explain the sequence data in absence of homoplasy (Hudson and Kaplan, 1985). The number of apparent homoplasies, $h$, corresponds to the minimal number of homoplasies that would be needed to explain the data in absence of recombination. The associated statistical test evaluates whether or not $h$ is compatible with the level of polymorphism if no recombination is involved. It is suitable for detecting recombination between fairly related strains with similar sequences, i.e. differing by less than 5\% (Maynard Smith and Smith, 1998).

\subsection{Phylogenetic analysis}

Phylogenetic analysis was performed using ClonalFrame software version 1.1 (Didelot and Falush, 2007). ClonalFrame grounds the reconstruction of the genealogical relationship between sequences on a model that accounts for both vertical transmission of the genetic material in cell lineage (the clonal frame) and the occurrence of recombination tracts of variable length. Divergence is generated by mutations as well as and by recombination events that consists of the localized replacement of the sequence by a divergent sequence. In addition to the genealogy of the clonal frame, the parameters of this model are the population mutation rate $(\theta)$, the population recombination rate $(R)$, the average length of the recombination tracts $(\delta)$ and the fraction of nucleotide divergence in sequences incorporated by recombination $(v)$. Population mutation and recombination rates correspond to the rates of accumulation of these events in two diverging lineages when time is measured in coalescent units; one coalescent unit of time being the average time to the last common ancestor for a pair of isolates sampled randomly within the population. Inference is carried out in a Bayesian framework using a MCMC (Markov Chain Monte Carlo) algorithm. The number of burn-in cycles of the MCMC algorithm and further iterations were both fixed at a number of 250,000 (five times the default settings). The thinning interval was set to 50 , resulting in a posterior sample of size 1000 . In this analysis, each ST was represented by a unique sequence and the algorithm was run simultaneously on the 7 loci without concatenating the sequences. Posterior samples were simulated using the default settings where all parameters are estimated or with given values for some parameters other than R. Robustness of the inferred topology for the genealogy with respect to the starting point of the algorithm was verified by comparing the results obtained with three available options for the initial tree: a fully unbalanced tree, a uniformly chosen coalescent tree and the scaled UPGMA tree. The estimated matrix of pairwise-distances was used to draw a phylogenetic tree using 
Table 1

Strains, allele types (ATs), sequence types (STs), biotopes, countries of isolation and subspecies.

\begin{tabular}{|c|c|c|c|c|c|c|c|c|c|c|c|c|}
\hline \multirow{2}{*}{$\begin{array}{l}\text { Strain } \\
\text { number }^{\mathrm{a}}\end{array}$} & \multirow{2}{*}{$\begin{array}{l}\text { Strain } \\
\text { name }\end{array}$} & \multicolumn{7}{|l|}{ AT } & \multirow[t]{2}{*}{ ST } & \multirow[t]{2}{*}{ Biotopes } & Country of & Subsp. \\
\hline & & $\overline{r p o B}$ & $a d k$ & pf1637 & $\operatorname{rec} A$ & $p f 169$ & fumc & $g t f$ & & & & \\
\hline I102 & CIRM-BIA472 & 1 & 1 & 3 & 4 & 1 & 3 & 1 & 43 & Swiss cheese & Finland & $\mathrm{S}$ \\
\hline $\mathrm{I} 50$ & CIRM-BIA122 & 1 & 1 & 3 & 4 & 1 & 3 & 2 & 28 & $N A^{b}$ & NA & $\mathrm{S}$ \\
\hline I77 & CIRM-BIA556 & 1 & 1 & 3 & 4 & 1 & 3 & 2 & 28 & Swiss cheese & Finland & S \\
\hline $\mathrm{I} 11$ & CIRM-BIA512 & 1 & 1 & 3 & 2 & 1 & 2 & 2 & 8 & Morbier cheese & France & $\mathrm{S}$ \\
\hline $\mathrm{I} 32$ & CIRM-BIA692 & 1 & 1 & 3 & 2 & 1 & 2 & 2 & 8 & Morbier cheese & France & $\mathrm{S}$ \\
\hline $\mathrm{I} 37$ & TL1001 & 1 & 1 & 3 & 2 & 1 & 2 & 2 & 8 & Cow milk & France & $\mathrm{S}$ \\
\hline 198 & CIRM-BIA630 & 1 & 1 & 3 & 2 & 1 & 2 & 2 & 8 & Swiss cheese & Finland & $\mathrm{S}$ \\
\hline I68 & CIRM-BIA547 & 1 & 1 & 3 & 2 & 1 & 6 & 2 & 32 & Swiss cheese & Finland & $\mathrm{S}$ \\
\hline 141 & TL1263 & 1 & 1 & 3 & 2 & 1 & 3 & 2 & 25 & Milking machine & France & S \\
\hline $\mathrm{I} 91$ & CIRM-BIA623 & 7 & 5 & 3 & 1 & 1 & 2 & 2 & 39 & Swiss cheese & Finland & $\mathrm{P}+$ \\
\hline I108 & CIRM-BIA121 & 1 & 2 & 6 & 1 & 1 & 1 & 2 & 44 & Swiss cheese & USA & $\mathrm{F}$ \\
\hline $\mathrm{I} 27$ & CIRM-BIA693 & 1 & 2 & 3 & 1 & 1 & 4 & 2 & 21 & Ras cheese & Egypt & S \\
\hline I64 & CIRM-BIA543 & 7 & 2 & 3 & 1 & 1 & 1 & 2 & 30 & Swiss cheese & Finland & $\mathrm{F}$ \\
\hline 196 & CIRM-BIA628 & 7 & 2 & 3 & 1 & 1 & 1 & 1 & 41 & Swiss cheese & Finland & $\mathrm{S}$ \\
\hline $\mathrm{I} 110$ & ITG P9 & 1 & 1 & 3 & 1 & 5 & 1 & 2 & 45 & NA & NA & S \\
\hline I3 & CIRM-BIA685 & 1 & 1 & 3 & 1 & 1 & 1 & 2 & 3 & Cow milk cheese & Brazil & S \\
\hline $\mathrm{I} 45$ & TL566 & 1 & 1 & 3 & 1 & 1 & 1 & 2 & 3 & Sbrinz cheese & Switzerland & $\mathrm{P}+$ \\
\hline I67 & CIRM-BIA546 & 1 & 1 & 3 & 1 & 1 & 1 & 2 & 3 & Swiss cheese & Finland & S \\
\hline $\mathrm{I} 74$ & CIRM-BIA553 & 1 & 1 & 3 & 1 & 1 & 1 & 2 & 3 & Cow milk & Finland & $\mathrm{P}-$ \\
\hline I105 & CIRM-BIA478 & 1 & 1 & 3 & 1 & 1 & 1 & 2 & 3 & Swiss cheese & Finland & $\mathrm{P}+$ \\
\hline I107 & CIRM-BIA488 & 1 & 1 & 3 & 1 & 1 & 1 & 2 & 3 & Swiss cheese & Finland & $\mathrm{P}-$ \\
\hline 129 & CIRM-BIA527 & 1 & 1 & 3 & 1 & 1 & 4 & 2 & 22 & Fribourg cheese & Switzerland & $\mathrm{F}$ \\
\hline $\mathrm{I} 62$ & CIRM-BIA541 & 1 & 1 & 3 & 1 & 1 & 4 & 2 & 22 & Swiss cheese & Finland & S \\
\hline $\mathrm{I} 14$ & CIRM-BIA516 & 3 & 1 & 3 & 1 & 1 & 1 & 2 & 11 & Yak milk cheese & Nepal & $\mathrm{S}$ \\
\hline $\mathrm{I} 21$ & CIRM-BIA684 & 3 & 1 & 3 & 1 & 3 & 1 & 2 & 15 & Cow milk cheese & Brazil & $\mathrm{S}$ \\
\hline $\mathrm{I} 12$ & CIRM-BIA513 & 1 & 1 & 3 & 2 & 1 & 1 & 1 & 9 & Ras cheese & Egypt & $S$ \\
\hline $\mathrm{I} 42$ & TL600 & 1 & 1 & 3 & 2 & 1 & 1 & 1 & 9 & Swiss cheese & Australia & $\mathrm{P}+$ \\
\hline I101 & CIRM-BIA701 & 1 & 1 & 3 & 2 & 1 & 1 & 1 & 9 & NA & Greece & $S$ \\
\hline I36 & CIRM-BIA481 & 1 & 1 & 3 & 2 & 1 & 1 & 1 & 9 & Swiss cheese & Finland & $\mathrm{S}$ \\
\hline $\mathrm{I} 54$ & CIRM-BIA533 & 1 & 1 & 3 & 2 & 1 & 1 & 1 & 9 & Swiss cheese & Finland & $\mathrm{S}$ \\
\hline $\mathrm{I} 75$ & CIRM-BIA554 & 1 & 1 & 3 & 2 & 1 & 1 & 1 & 9 & Swiss cheese & Finland & $\mathrm{S}$ \\
\hline 194 & CIRM-BIA626 & 1 & 1 & 3 & 2 & 1 & 1 & 1 & 9 & Swiss cheese & Finland & $\mathrm{S}$ \\
\hline $\mathrm{I} 22$ & CIRM-BIA688 & 1 & 1 & 3 & 2 & 4 & 1 & 1 & 16 & Cow milk & France & $S$ \\
\hline I19 & CIRM-BIA682 & 1 & 1 & 3 & 1 & 1 & 1 & 1 & 14 & Cow milk & France & $\mathrm{P}+$ \\
\hline $\mathrm{I} 31$ & CIRM-BIA686 & 1 & 1 & 3 & 1 & 1 & 1 & 1 & 14 & Goat milk cheese & France & $S$ \\
\hline $\mathrm{I} 40$ & TL1079 & 1 & 1 & 3 & 1 & 1 & 1 & 1 & 14 & Cow milk & France & S \\
\hline $\mathrm{I} 28$ & CIRM-BIA511 & 1 & 1 & 3 & 1 & 1 & 1 & 1 & 14 & Swiss cheese & Switzerland & $\mathrm{P}+$ \\
\hline $\mathrm{I} 55$ & CIRM-BIA534 & 1 & 1 & 3 & 1 & 1 & 1 & 1 & 14 & Swiss cheese & Finland & $S$ \\
\hline $\mathrm{I} 79$ & CIRM-BIA611 & 1 & 1 & 3 & 1 & 1 & 1 & 1 & 14 & Swiss cheese & Finland & $\mathrm{P}+$ \\
\hline 192 & CIRM-BIA624 & 1 & 1 & 3 & 1 & 1 & 1 & 1 & 14 & Swiss cheese & Finland & $\mathrm{P}+$ \\
\hline 123 & CIRM-BIA689 & 1 & 1 & 3 & 1 & 1 & 5 & 1 & 17 & Tomme Agen Cheese & France & $S$ \\
\hline 146 & TL1089 & 1 & 1 & 3 & 1 & 1 & 5 & 1 & 17 & Cow milk & France & $\mathrm{P}+$ \\
\hline 187 & CIRM-BIA619 & 1 & 1 & 3 & 1 & 1 & 4 & 1 & 37 & Swiss cheese & Finland & $\mathrm{S}$ \\
\hline $\mathrm{I} 44$ & TL929 & 1 & 1 & 3 & 2 & 1 & 5 & 2 & 27 & Cow milk & France & $\mathrm{P}+$ \\
\hline $\mathrm{I} 58$ & CIRM-BIA537 & 1 & 1 & 3 & 2 & 1 & 5 & 2 & 27 & Swiss cheese & Finland & $\mathrm{P}-$ \\
\hline I63 & CIRM-BIA542 & 1 & 1 & 3 & 2 & 1 & 5 & 2 & 27 & Swiss cheese & Finland & $\mathrm{P}+$ \\
\hline I65 & CIRM-BIA544 & 1 & 1 & 3 & 2 & 1 & 5 & 2 & 27 & Swiss cheese & Finland & $\mathrm{P}+$ \\
\hline I69 & CIRM-BIA548 & 1 & 1 & 3 & 2 & 1 & 5 & 2 & 27 & Swiss cheese & Finland & S \\
\hline I80 & CIRM-BIA612 & 1 & 1 & 3 & 2 & 1 & 5 & 2 & 27 & Swiss cheese & Finland & $\mathrm{P}+$ \\
\hline I84 & CIRM-BIA616 & 1 & 1 & 3 & 2 & 1 & 5 & 2 & 27 & Swiss cheese & Finland & S \\
\hline I85 & CIRM-BIA617 & 1 & 1 & 3 & 2 & 1 & 5 & 2 & 27 & Swiss cheese & Finland & $\mathrm{F}$ \\
\hline I106 & CIRM-BIA482 & 1 & 1 & 3 & 2 & 1 & 5 & 2 & 27 & Swiss cheese & Finland & S \\
\hline I66 & CIRM-BIA545 & 1 & 1 & 3 & 2 & 1 & 1 & 2 & 31 & Swiss cheese & Finland & $\mathrm{P}+$ \\
\hline 143 & CIRM-BIA456 & 6 & 1 & 3 & 2 & 1 & 1 & 4 & 26 & Raclette cheese & France & $S$ \\
\hline 188 & CIRM-BIA620 & 2 & 2 & 3 & 1 & 1 & 1 & 1 & 38 & Cow milk & Finland & $\mathrm{S}$ \\
\hline 199 & CIRM-BIA528 & 2 & 1 & 3 & 1 & 1 & 1 & 2 & 42 & Swiss cheese & Finland & $\mathrm{S}$ \\
\hline I78 & CIRM-BIA610 & 1 & 1 & 4 & 5 & 1 & 1 & 2 & 34 & Swiss cheese & Finland & $\mathrm{S}$ \\
\hline $\mathrm{I} 24$ & CIRM-BIA704 & 2 & 1 & 2 & 3 & 1 & 1 & 2 & 18 & Beaufort cheese & France & S \\
\hline 18 & CIRM-BIA687 & 2 & 2 & 1 & 1 & 1 & 3 & 3 & 6 & Morbier cheese & France & $\mathrm{P}-$ \\
\hline I16 & CIRM-BIA530 & 1 & 1 & 2 & 1 & 1 & 4 & 2 & 12 & Swiss cheese & Finland & $\mathrm{P}-$ \\
\hline $\mathrm{I} 30$ & CIRM-BIA531 & 1 & 1 & 2 & 1 & 1 & 4 & 2 & 12 & Swiss cheese & Finland & S \\
\hline $\mathrm{I} 53$ & CIRM-BIA532 & 1 & 1 & 2 & 1 & 1 & 4 & 2 & 12 & Swiss cheese & Finland & S \\
\hline I56 & CIRM-BIA535 & 1 & 1 & 2 & 1 & 1 & 4 & 2 & 12 & Swiss cheese & Finland & $\mathrm{P}-$ \\
\hline I60 & CIRM-BIA539 & 1 & 1 & 2 & 1 & 1 & 4 & 2 & 12 & Swiss cheese & Finland & S \\
\hline I61 & CIRM-BIA540 & 1 & 1 & 2 & 1 & 1 & 4 & 2 & 12 & Swiss cheese & Finland & $\mathrm{F}$ \\
\hline I70 & CIRM-BIA549 & 1 & 1 & 2 & 1 & 1 & 4 & 2 & 12 & Swiss cheese & Finland & $\mathrm{F}$ \\
\hline $\mathrm{I} 72$ & CIRM-BIA551 & 1 & 1 & 2 & 1 & 1 & 4 & 2 & 12 & Swiss cheese & Finland & $\mathrm{P}-$ \\
\hline 176 & CIRM-BIA555 & 1 & 1 & 2 & 1 & 1 & 4 & 2 & 12 & Swiss cheese & Finland & $\mathrm{P}-$ \\
\hline I104 & CIRM-BIA476 & 1 & 1 & 2 & 1 & 1 & 4 & 2 & 12 & Swiss cheese & Finland & $\mathrm{P}-$ \\
\hline I71 & CIRM-BIA550 & 1 & 4 & 2 & 1 & 1 & 4 & 2 & 33 & Swiss cheese & Finland & S \\
\hline 12 & CIRM-BIA123 & 1 & 1 & 2 & 1 & 1 & 2 & 1 & 2 & Morbier cheese & France & $\mathrm{S}$ \\
\hline $\mathrm{I} 18$ & CIRM-BIA8 & 1 & 1 & 2 & 1 & 1 & 2 & 1 & 2 & Cow milk & France & $\mathrm{S}$ \\
\hline 189 & CIRM-BIA621 & 1 & 1 & 2 & 1 & 1 & 2 & 1 & 2 & Swiss cheese & Finland & $\mathrm{P}+$ \\
\hline
\end{tabular}


Table 1 (continued)

\begin{tabular}{|c|c|c|c|c|c|c|c|c|c|c|c|c|}
\hline \multirow{2}{*}{$\begin{array}{l}\text { Strain } \\
\text { number }^{\mathrm{a}}\end{array}$} & \multirow{2}{*}{$\begin{array}{l}\text { Strain } \\
\text { name }\end{array}$} & \multicolumn{7}{|l|}{ AT } & \multirow[t]{2}{*}{ ST } & \multirow[t]{2}{*}{ Biotopes } & \multirow{2}{*}{$\begin{array}{l}\text { Country of } \\
\text { isolation }\end{array}$} & \multirow[t]{2}{*}{ Subsp. } \\
\hline & & rров & $a d k$ & pf1637 & recA & pf169 & fumC & $g t f$ & & & & \\
\hline I9 & CIRM-BIA41 & 1 & 1 & 2 & 1 & 1 & 2 & 2 & 7 & Comté cheese & France & $\mathrm{S}$ \\
\hline 139 & TL1041 & 1 & 1 & 2 & 1 & 1 & 2 & 2 & 7 & Cow milk & France & $\mathrm{S}$ \\
\hline 147 & TL1122 & 1 & 1 & 2 & 1 & 1 & 2 & 2 & 7 & Ewe milk & France & $\mathrm{S}$ \\
\hline 149 & TL1045 & 1 & 1 & 2 & 1 & 1 & 2 & 2 & 7 & Cow milk & France & S \\
\hline I82 & CIRM-BIA614 & 1 & 1 & 2 & 2 & 1 & 2 & 2 & 36 & Swiss cheese & Finland & $\mathrm{S}$ \\
\hline $\mathrm{I} 25$ & CIRM-BIA690 & 1 & 1 & 2 & 2 & 1 & 5 & 2 & 19 & Leerdammer cheese & France & $\mathrm{F}$ \\
\hline $\mathrm{I} 26$ & CIRM-BIA691 & 5 & 3 & 2 & 2 & 1 & 1 & 2 & 20 & Abondance cheese & France & $\mathrm{S}$ \\
\hline I59 & CIRM-BIA538 & 5 & 1 & 2 & 2 & 1 & 1 & 2 & 29 & Swiss cheese & Finland & $S$ \\
\hline $\mathrm{I} 112$ & ITG P20 & 1 & 1 & 2 & 2 & 6 & 1 & 2 & 46 & NA & NA & $\mathrm{S}$ \\
\hline $\mathrm{I} 5$ & CIRM-BIA134 & 1 & 1 & 2 & 2 & 1 & 1 & 2 & 5 & Raclette cheese & France & $\mathrm{P}-$ \\
\hline I6 & CIRM-BIA135 & 1 & 1 & 2 & 2 & 1 & 1 & 2 & 5 & Ewe milk & France & S \\
\hline $\mathrm{I} 10$ & CIRM-BIA510 & 1 & 1 & 2 & 2 & 1 & 1 & 2 & 5 & Beaufort cheese & France & $\mathrm{S}$ \\
\hline 148 & TL1004 & 1 & 1 & 2 & 2 & 1 & 1 & 2 & 5 & Cow milk & France & $\mathrm{P}-$ \\
\hline I83 & CIRM-BIA615 & 1 & 1 & 2 & 2 & 1 & 1 & 2 & 5 & Swiss cheese & Finland & $\mathrm{S}$ \\
\hline 193 & CIRM-BIA625 & 1 & 1 & 2 & 2 & 1 & 1 & 2 & 5 & Swiss cheese & Finland & $\mathrm{P}-$ \\
\hline $\mathrm{I} 81$ & CIRM-BIA613 & 1 & 1 & 5 & 2 & 1 & 1 & 2 & 35 & Cow milk & Finland & $\mathrm{S}$ \\
\hline $\mathrm{I} 17$ & CIRM-BIA7 & 4 & 1 & 2 & 2 & 1 & 1 & 2 & 13 & Cow milk & France & $\mathrm{P}+$ \\
\hline $\mathrm{I} 52$ & CIRM-BIA119 & 4 & 1 & 2 & 2 & 1 & 1 & 2 & 13 & Gruyere cheese & France & $\mathrm{P}+$ \\
\hline $\mathrm{I} 73$ & CIRM-BIA552 & 4 & 1 & 2 & 2 & 1 & 1 & 2 & 13 & Swiss cheese & Finland & $\mathrm{P}+$ \\
\hline I38 & TL1014 & 4 & 1 & 2 & 2 & 1 & 1 & 1 & 24 & Cow milk & France & $\mathrm{S}$ \\
\hline $\mathrm{I} 51$ & TL214 & 4 & 1 & 2 & 2 & 1 & 1 & 1 & 24 & Fribourg cheese & France & $\mathrm{P}+$ \\
\hline I113 & ITG P23 & 4 & 1 & 2 & 2 & 1 & 1 & 1 & 24 & NA & NA & $\mathrm{S}$ \\
\hline I1 & CIRM-BIA $1^{\mathrm{T}}$ & 1 & 1 & 1 & 1 & 1 & 1 & 1 & 1 & NA & The Netherlands & $\mathrm{S}$ \\
\hline $\mathrm{I} 34$ & CIRM-BIA9 & 1 & 1 & 1 & 1 & 1 & 1 & 1 & 1 & Cheese & The Netherlands & $\mathrm{S}$ \\
\hline $\mathrm{I} 100$ & CIRM-BIA702 & 1 & 1 & 1 & 1 & 1 & 1 & 1 & 1 & NA & Greece & $\mathrm{S}$ \\
\hline 17 & CIRM-BIA141 & 1 & 1 & 1 & 1 & 1 & 1 & 1 & 1 & Wheat & France & $S$ \\
\hline $\mathrm{I} 20$ & CIRM-BIA683 & 1 & 1 & 1 & 1 & 1 & 1 & 1 & 1 & Wheat & France & $\mathrm{S}$ \\
\hline $\mathrm{I} 33$ & CIRM-BIA515 & 1 & 1 & 1 & 1 & 1 & 1 & 1 & 1 & Straw & France & $\mathrm{S}$ \\
\hline $\mathrm{I} 15$ & CIRM-BIA529 & 1 & 1 & 1 & 1 & 1 & 1 & 1 & 1 & Swiss cheese & Finland & $\mathrm{S}$ \\
\hline I86 & CIRM-BIA618 & 1 & 1 & 1 & 1 & 1 & 1 & 1 & 1 & Swiss cheese & Finland & $\mathrm{S}$ \\
\hline 190 & CIRM-BIA622 & 1 & 1 & 1 & 1 & 1 & 1 & 1 & 1 & Swiss cheese & Finland & S \\
\hline 197 & CIRM-BIA629 & 1 & 1 & 1 & 1 & 1 & 1 & 1 & 1 & Swiss cheese & Finland & $\mathrm{S}$ \\
\hline I103 & CIRM-BIA474 & 1 & 1 & 1 & 1 & 1 & 1 & 1 & 1 & Swiss cheese & Finland & $S$ \\
\hline 14 & CIRM-BIA132 & 1 & 1 & 1 & 1 & 2 & 1 & 1 & 4 & Cow milk cheese & USA & $\mathrm{S}$ \\
\hline I13 & CIRM-BIA514 & 1 & 1 & 1 & 1 & 1 & 1 & 2 & 10 & Hay & France & $\mathrm{F}$ \\
\hline I111 & ITG P18 & 1 & 1 & 1 & 1 & 1 & 1 & 2 & 10 & NA & NA & $\mathrm{F}$ \\
\hline 195 & CIRM-BIA627 & 1 & 1 & 1 & 1 & 1 & 5 & 2 & 40 & Swiss cheese & Finland & $\mathrm{F}$ \\
\hline I35 & CIRM-BIA118 & 1 & 1 & 1 & 2 & 1 & 1 & 2 & 23 & Gruyere cheese & France & $\mathrm{S}$ \\
\hline I109 & CIRM-BIA508 & 1 & 1 & 1 & 2 & 1 & 1 & 2 & 23 & Gruyere cheese & France & $\mathrm{S}$ \\
\hline $\mathrm{I} 57$ & CIRM-BIA536 & 1 & 1 & 1 & 2 & 1 & 1 & 2 & 23 & Swiss cheese & Finland & $\mathrm{S}$ \\
\hline
\end{tabular}

a Strains are listed according to their order in the phylogenetic tree (Fig. 1). Abbreviations for subspecies: F, P. freudenreichii subsp. freudenreichii; S, P. freudenreichii subsp. shermanii; $\mathrm{P}+$, P. freudenreichii "pheno+" able to use lactose and nitrate; P-, P. freudenreichii "pheno-" unable to use lactose and nitrate.

b Not available.

neighbor-joining. From the posterior sample, the support for each internal branch was assessed as the proportion of trees possessing the branch. The respective contribution of recombination and mutation to the nucleotide changes was computed from the output of the MCMC algorithm as the "r/m" ratio (Guttman and Dykhuizen, 1994), with $r$ expressed as the product of $\delta, v$ and the recombination rate $\mathrm{R}$, and $\mathrm{m}$ as the mutation rate $\theta$.

\subsection{Nucleotide sequence accession numbers}

Nucleotide sequences have been deposited in EMBL under accession number FN650812 to FN650924 ( $r p o B)$, FN650925 to FN651037 (adk), FN651038 to FN651150 ( $p f 1637$ ), FN651151 to FN651263 (recA), FN651264 to FN651376 (pf169), FN651277 to FN651489 (fumC) and FN651490 to FN651602 (gtf).

Table 2

Genes, primer sequences, annealing temperatures and amplicon sizes.

\begin{tabular}{|c|c|c|c|c|c|c|c|}
\hline \multirow[t]{2}{*}{ Gene } & \multicolumn{4}{|l|}{ Primer } & \multirow{2}{*}{$\begin{array}{l}\text { Annealing } \\
\text { temperature }\left({ }^{\circ} \mathrm{C}\right)\end{array}$} & \multirow{2}{*}{$\begin{array}{l}\text { Amplicon } \\
\text { size (bp) }\end{array}$} & \multirow[t]{2}{*}{ References } \\
\hline & Forward & & Reverse & & & & \\
\hline$r p o B$ & rроB2-F & GAGTTCGGCGAGTACGAGTC & rpoB2-R & GTGCCGAAGAACTCCTTGAG & 58 & 530 & \\
\hline adk & adk-F3 & GCGATCTCAACCGGAGAC & adk-R3 & GACTTGTAGGCGTCGAGCAG & 58 & 482 & \\
\hline pf1637 & pf1637-F & TTCCCTGGATGCCTATTTCA & pf1637-R & CGACTCCATGTCGTAGAGCA & 58 & 580 & \\
\hline recA & recA-F & CAATGAGATCGTGGGAAACC & recA-R & ACCGTAGCCTTACCGGACTT & 58 & 414 & \\
\hline pf169 & pf169-F & TGATCGAATATCCGGTGCAG & pf169-R & GATAGCAGGCAAGCGCATAG & 59 & 411 & \\
\hline fumC & fumC2-F & GAACGCCAATGAGGTGATCT & fumC2-R & GGTCTCGTCGCTGATCTTCT & 58 & 448 & \\
\hline$g t f$ & Gtf-F2 & CAGTCGGTGAAGAACCGCTACG & Gtf-R1 & CGGCAGGGCATAGGTGAACAAC & 60 & 342 & Deutsch et al. (2008) \\
\hline
\end{tabular}




\section{Results}

\subsection{MLST scheme and allelic diversity}

A MLST database was created to host the data generated from the 113 P. freudenreichii strains (http://www.pasteur.fr/recherche/genopole/PF8/ $\mathrm{mlst} /$ ) (Jolley et al., 2004). The size of the seven gene fragments considered in this MLST scheme ranged from $234 \mathrm{bp}$ ( $g t f$ ) to $477 \mathrm{bp}$ (pf1637) (Table 3). The mean G + C content of genes varied from $62.30 \%$ (recA) to $67.32 \%$ (adk). The number of allele types (ATs) was as follows: 4 ATs for $g t f, 5$ ATs for $a d k$ and $r e c A, 6$ ATs for pf1637, pf169 and fumC, and 7 ATs for $r p o B$. The combination of the ATs at the seven loci permitted the detection of 46 sequence types (STs) among the 113 strains. Seventeen STs were identified more than once (Table 1). ST-1 was the most frequent ST and gathered 11 strains, directly followed by ST-12 (10 strains) and ST-27 (9 strains).

The values of the summary statistics depicting polymorphisms at the seven loci are reported in Table 3. Considering the 2409 nucleotides of the seven gene fragments together, there were 55 single nucleotide polymorphisms (SNPs), which represented a proportion of $2.28 \%$ of the concatenated sequences. The number of SNPs varied from 3 (1.28\% of the allele sequence) at $g t f$ locus to 15 (3.14\% of the allele sequence) at pf1637 locus. The level of pairwise nucleotide diversity $(\pi)$, i.e. the percentage of positions that differed on average in two strains, was $0.46 \%$ for the concatenated sequences but fluctuated from $0.03 \%$ (pf169) to $1.33 \%$ (pf1637). Only 15 SNPs among the 55 were non-synonymous $\left(\mathrm{S}_{\text {nonsyn }}\right)$.

\subsection{Evidence for recombination events}

The contribution of recombination events to the sequence polymorphisms was detected by means of two statistics, the Hudson and Kaplan's lower bound on the number of recombination events $\left(R_{\min }\right)$ and the minimal number of apparent homoplasies $(h)$ (see materials and methods). Values were computed for each locus and for the whole dataset as reported in Table $3 . R_{\min }$ was 1 for pf1637 and rpoB and 0 for all the other loci. The low values of $R_{\min }$ at the different loci can be interpreted as an absence of evidence for significant intralocus recombination but $R_{\min }$ reached 7 for the concatenated sequences, indicating recombination between loci. The statistic $h$ is the minimal number of homoplasy (reversions or parallel mutations in independent lineages) that would be needed in absence of recombination. It is computed as the difference between the number of polymorphisms and the minimal number of mutations along a tree for explaining the sequences. As for $R_{\min }, h$ was equal to 0 or 1 when the loci were considered separately. However, $h$ obtained for the concatenated sequences $(h=54)$ was greatly higher than the sum of the seven independent $h$ values at the different loci $(h=2)$. This value was significantly higher than the expected value in absence of recombination $(p$-value $<0.005)$ and confirmed the non ambiguous contribution of recombination between loci to the generation of the STs.

\subsection{Population structure}

In order to attempt the reconstruction of a phylogenetic tree despite the presence of recombination, the sequences of the seven loci were analyzed all together with ClonalFrame. This software explicitly accounts for recombination in the history of the sample. The consensus phylogenetic tree derived from the posterior sample obtained with the default settings, where all parameters are estimated, is presented in Fig. 1. This tree contains 14 internal branches with posterior support greater than $80 \%$, suggesting that the level of recombination was not high enough to obliterate the signal on the relationships between the cell lineages identified by the STs. The topology of the tree was robust with respect to the starting point of the algorithm and to the set of parameters left free in the estimation. ClonalFrame generates parameter estimates that allow evaluating the relative contributions of recombination and mutation to the nucleotide changes in the evolution of a cell lineage, summarized in the $\mathrm{r} / \mathrm{m}$ ratio (Guttman and Dykhuizen, 1994). Fig. 2 shows the posterior distribution of the $\mathrm{r} / \mathrm{m}$ ratio. The algorithm was also run with fixed values for the population mutation rate $(\theta)$ and for the fraction of nucleotide divergence in recombination tracts $(v)$ (Vos and Didelot, 2009). The two parameters were set to 0.005 nucleotide changes per site. This particular value was selected to agree with two estimators of $\theta$ : the pairwise nucleotide diversity estimator $(\pi)$, and the Watterson's estimator $\left(\theta_{\mathrm{w}}\right)$ that relies on the comparison between the number of SNPs and the sample size (Watterson, 1978). The value of $\pi$ is $0.0046 \mathrm{bp}^{-1}$ (Table 3 ) and the value of $\theta_{\mathrm{w}}$ varies between $0.0043 \mathrm{bp}^{-1}$, when multiple occurrences of the same ST are taken into account, and $0.0052 \mathrm{bp}^{-1}$, when multiple occurrences are omitted. As shown in Fig. 2, the posterior distribution of $\mathrm{r} / \mathrm{m}$ has its mode ranging from 1 to 2 , depending on whether the default settings or fixed values for $\theta$ and $v$ are used.

\subsection{Phenotypic and dairy origin variability}

The differentiation of the two $P$. freudenreichii subspecies was performed to investigate the possible relationships between STs and

Table 3

Sequence variations and polymorphisms at seven loci.

\begin{tabular}{|c|c|c|c|c|c|c|c|c|c|}
\hline \multirow[t]{2}{*}{ Gene } & \multicolumn{3}{|l|}{ Locus } & \multicolumn{4}{|c|}{ Polymorphism } & \multicolumn{2}{|c|}{ Recombination } \\
\hline & Position $(\mathrm{kbp})^{\mathrm{a}}$ & Length (bp) & Mean $\mathrm{G}+\mathrm{C}$ content $(\mathrm{mol} \%)$ & $\mathrm{S}^{\mathrm{b}}$ & $\mathrm{S}_{\text {nonsyn }}{ }^{\mathrm{c}}$ & No. of AT & $\pi\left(b p^{-1}\right)^{d}$ & $R_{\min }^{\mathrm{e}}$ & $h^{\mathrm{f}}$ \\
\hline rрoв & 656 & 429 & 65.22 & 11 & 2 & 7 & 0.0020 & 1 & 1 \\
\hline$a d k$ & 695 & 303 & 67.32 & 7 & 1 & 5 & 0.0013 & 0 & 0 \\
\hline pf1637 & 1438 & 477 & 66.07 & 15 & 3 & 6 & 0.0133 & 1 & 1 \\
\hline recA & 1471 & 312 & 62.30 & 4 & 3 & 5 & 0.0018 & 0 & 0 \\
\hline pf169 & 1577 & 309 & 66.34 & 5 & 3 & 6 & 0.0003 & 0 & 0 \\
\hline fumC & 1784 & 345 & 65.30 & 10 & 2 & 6 & 0.0071 & 0 & 0 \\
\hline gtf & 2089 & 234 & 65.81 & 3 & 1 & 4 & 0.0021 & 0 & 0 \\
\hline \multicolumn{10}{|l|}{ Total } \\
\hline Sum & & 2409 & - & 55 & 15 & - & 0.0046 & 2 & 2 \\
\hline Concatenation & & 2409 & - & 55 & 15 & $46^{\mathrm{g}}$ & 0.0046 & 7 & $54^{* *}$ \\
\hline
\end{tabular}

a Chromosomal position on the complete genome (2,616,384 bp) of strain CIRM-BIA1 ${ }^{\mathrm{T}}$.

b Number of single nucleotide polymorphisms (SNPs).

c Number of non-synonymous SNPs.

d Average level of pairwise nucleotide diversity per site.

e Hudson and Kaplan's lower bound for the number of recombination.

${ }^{f}$ Minimal number of apparent homoplasies (**, $\left.P=0.005\right)$.

${ }^{g}$ Number of STs. 


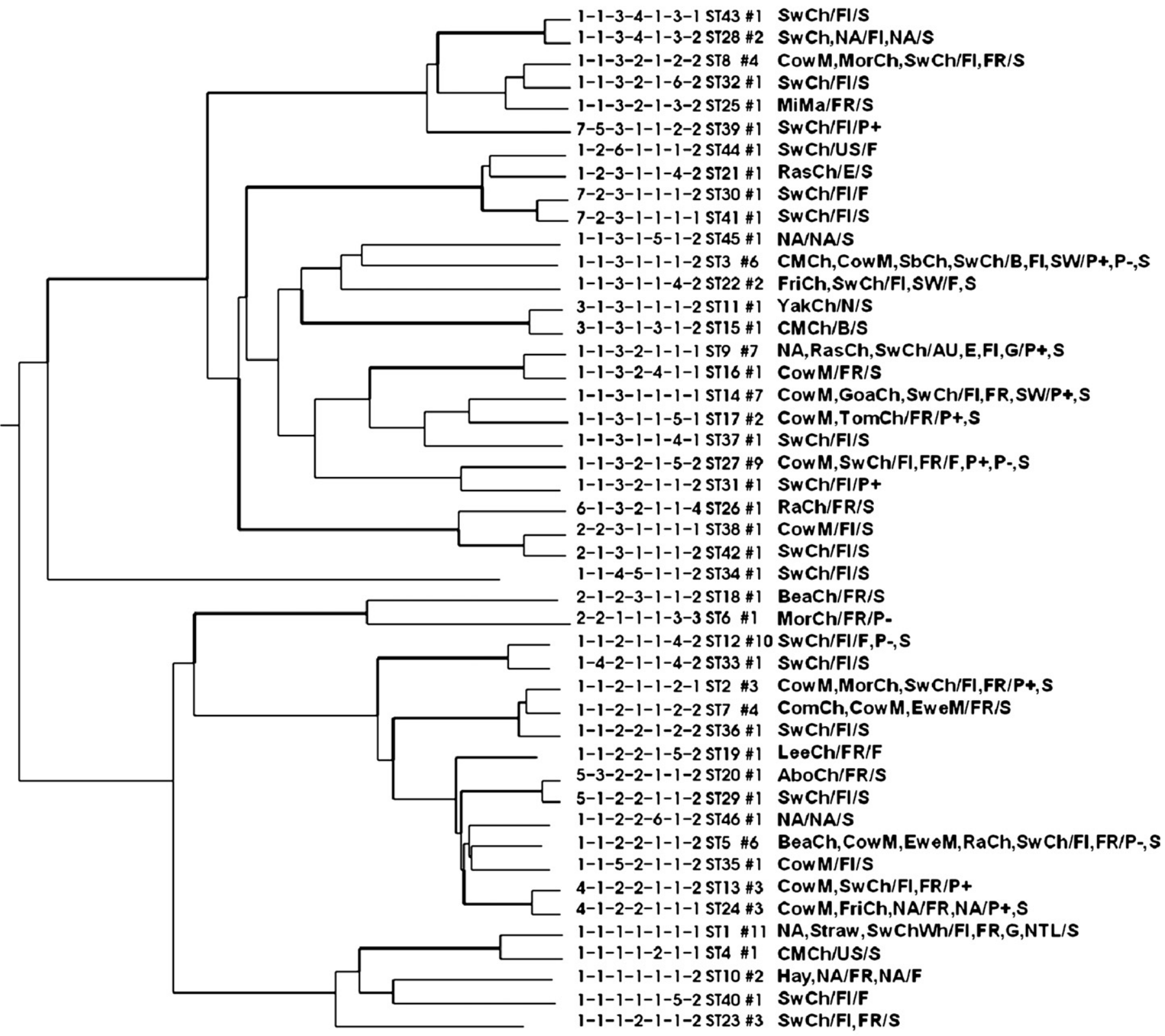

0.1 coalescent units

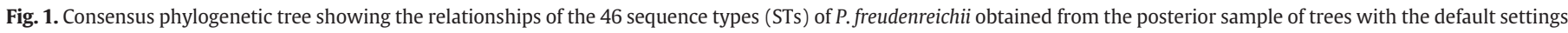

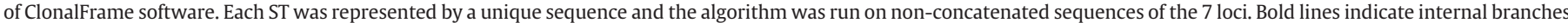

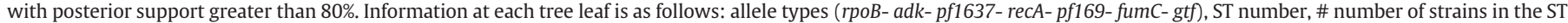

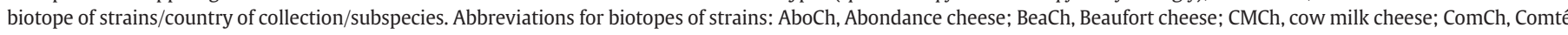

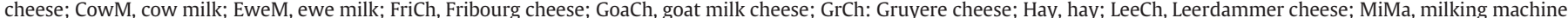

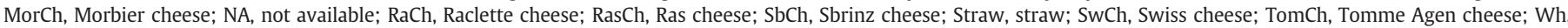

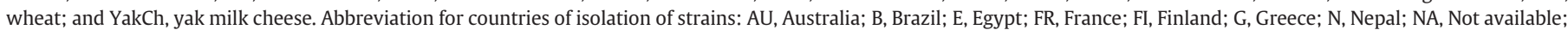

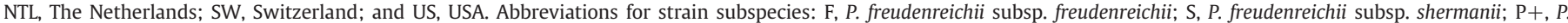
freudenreichii "pheno+" able to use lactose and nitrate; and P-, P. freudenreichii "pheno-" unable to use lactose and nitrate.

subspecies. It was conducted by testing the strains ability to reduce nitrate and to ferment lactose. Namely, P. freudenreichii subsp. shermanii is identified by its ability to use lactose but does not show a nitrate reductase activity, whereas $P$. freudenreichii subsp. freudenreichii cannot use lactose but shows a nitrate reductase activity. The results are reported in Table 1 . As a control, the type strains CIRM$\mathrm{BIA1}^{\mathrm{T}}\left(\mathrm{CIP} 103027^{\mathrm{T}}\right)$ and CIRM-BIA121 (CIP103026) were respectively recognized as $P$. freudenreichii subsp. shermanii and $P$. freudenreichii subsp. freudenreichii. A total of 72 P. freudenreichii subsp. shermanii and $10 \mathrm{P}$. freudenreichii subsp. freudenreichii strains could be unambiguously recognized. For 31 strains, subspecies assignment was not possible because either they fermented lactose and reduced nitrate (19 strains labeled "pheno+"), or neither fermented lactose nor reduced nitrate (12 strains labeled "pheno-"). The strains exhibiting the different combinations of phenotypes were distributed randomly over the tree (Fig. 1). For example, ST-27 brought together strains displaying the four subspecies phenotypes. Moreover, no specific group of strains was noticeable and no link could be observed between STs and the biotopes of strains (Swiss cheese, other cheeses, or milk). For example, strains from Swiss cheese displayed various STs 


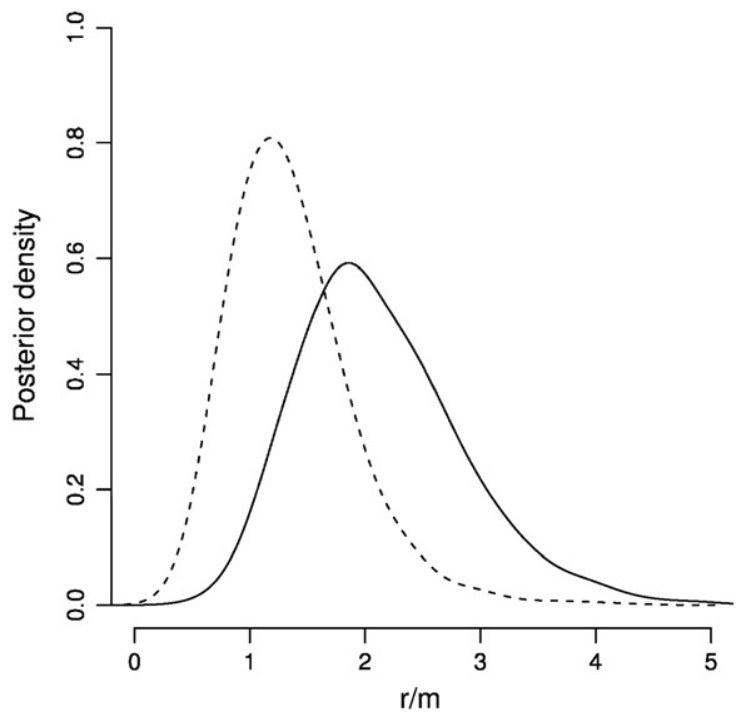

Fig. 2. Posterior distribution of the $\mathrm{r} / \mathrm{m}$ ratio estimated with ClonalFrame software using (- - -) the default settings for parameter estimation or (-) fixed values for the population mutation parameter $(\theta)$ and the amount of nucleotide divergence in sequences incorporated by recombination $(v)$.

and were spread all over the phylogenetic tree. Four strains isolated from plants and one strain isolated from milking equipment were also included in the study for comparison with strains of dairy origin. They exhibited no particular trend with respect to their position in the tree.

\section{Discussion}

MLST has proven to be useful to characterize many bacterial species and has largely been described formerly (Maiden, 2006; Maiden et al., 1998). The aim of this study was to understand the structure of the dairy population of $P$. freudenreichii. This was achieved by developing the first MLST scheme for a Propionibacterium species. The seven selected loci are conserved at the species level, scattered on the chromosome, and exhibit a G $+C$ content typical of $P$. freudenreichii genome (Falentin et al., 2010), suggesting that they have not been recently acquired in $P$. freudenreichii. In addition, the majority of SNPs reported here are synonymous, indicating that the selected genes are not under strong positive selection for amino acid changes. Thus, the seven genes are suitable for being used in population genetic analyses as representative of the core genome (Petersen et al., 2009).

This study revealed a low level of nucleotide polymorphism in the $P$. freudenreichii core genome, characterized by a small proportion of polymorphic sites $(1.28 \%$ to $3.14 \%)$ and low pairwise nucleotide diversity $\left(\pi=0.0046 \mathrm{bp}^{-1}\right)$. The value of the Watterson's estimate of the population mutation rate $\left(\theta_{\mathrm{w}} \sim 0.0043-0.0052 \mathrm{bp}^{-1}\right)$ was lower than the estimates reported for the 16 bacterial species considered in the comparative analysis of Perez-Losada et al. (Perez-Losada et al., 2006) and can thus be considered as low. The level of nucleotide polymorphism in P. freudenreichii is nevertheless slightly higher than that reported for Flavobacterium psychrophilum (Nicolas et al., 2008) and 0 . oeni (Bilhere et al., 2009). The extent of the natural biotope of $P$. freudenreichii being unknown, it is tempting to interpret the small genetic diversity of the species as an indication of a limited effective population size that might be compatible, for example, with a natural biotope dependant on cattle. Recombination events are at least as important as mutation events in the accumulation of sequence changes with time along $P$. freudenreichii cell lineages. The value of the $\mathrm{r} / \mathrm{m}$ ratio estimated to be comprised between 1 and 2 could be considered as intermediate when compared to 48 other species (Vos and Didelot, 2009). Characteristics that may be related to the exchange of genetic material by homologous recombination are found in the P. freudenreichii genome. Particularly, the genome of the CIRM-BIA $1^{\mathrm{T}}$ strain carries 34 integrase loci and 73 transposase loci, and insertion sequences account for $3.5 \%$ of the total genome (Falentin et al., 2010). Some $P$. freudenreichii strains contain plasmids that can also play a role in genetic exchanges (Rehberger and Glatz, 1990).

The different lineages in the $P$. freudenreichii population as identified by the STs are not restricted to a particular dairy biotope (Swiss cheese, other cheeses, or milk). During the "cooking" of the curd in Swiss cheese manufacture, the heat treatment $\left(\sim 50-55^{\circ} \mathrm{C}\right.$ for about $30 \mathrm{~min}$ ) is probably the main stress encountered by bacteria and the existence of thermotolerant and thermosensitive $P$. freudenreichii strains has clearly been demonstrated (Anastasiou et al., 2006). Strains isolated from Swiss cheese are thus likely to be the most thermotolerant strains among the studied strains. However, the strains from Swiss cheese were disseminated over the phylogenetic tree, as were the strains from other dairy biotopes. Different results have been reported regarding the connections between STs and strain origins in non-pathogenic bacteria. STs helped discriminating $L$. casei strains depending on their biotopes of isolation (cheese or silage) whereas they did not discriminate L. plantarum strains (Cai et al., 2007; de las Rivas et al., 2006). As for biotopes, geographical origins did not correlate with particular location in the tree. This could be a consequence of the probable impact of the worldwide trade of starters and cheeses on strain dissemination.

The relationships between the $P$. freudenreichii population structure and the subspecies definition were investigated. Two additional phenotypes ("pheno+" and "pheno-") are detected along with the classical P. freudenreichii subsp. freudenreichii and P. freudenreichii subsp. shermanii, based on the utilization of lactose and nitrate by strains. These two additional phenotypes have also occasionally been mentioned in former works (de Carvalho et al., 1994; Moore and Holdeman, 1974; Vorobjeva, 1999). According to nomenclature standards (Staley and Krieg, 1984), it would be conceivable to distinguish four subspecies rather than two. From an evolutionary perspective, an important finding is however that the lineages defined by the STs do not gather strains with the same phenotype. This gives a strong indication that the $P$. freudenreichii subspecies definition does not reflect the ancestral relationships between strains, and thereby provides an explanation for earlier reports on the difficulty to identify $P$. freudenreichii subspecies using molecular methods (Dasen et al., 1998; Fessler et al., 1999; Tilsala-Timisjarvi and Alatossava, 2001). This contrasts for instance with the case of Lactococcus lactis for which MLST results correlate with subspecies (lactis or cremoris) definition (Rademaker et al., 2007). Our results suggest that the phenotypic characteristics on which is based the subspecies definition are prone to recurrent changes in $P$. freudenreichii. The chromosomal context of the genes responsible for these phenotypes gives additional weight to this hypothesis. In the CIRM-BIA $1^{\mathrm{T}}$ strain, the genes coding for lactose fermentation are surrounded by integrases and transposases and the gene coding for nitrate degradation is disrupted by a frameshift (Falentin et al., 2010).

This study shows that the $P$. freudenreichii species constitutes a cohesive population with a low level of polymorphisms, and in which homologous recombination contributes to the generation of new allele combinations. Each $P$. freudenreichii lineage as defined by the STs is not restricted to a particular dairy biotope and can exhibit substantial phenotypic diversity.

\section{Acknowledgments}

We thank Pascal Le Bourgeois for his comments on the manuscript, Victoria Chuat for the preparation of strains, and Sylvain Brisse and Jean-Michel Thiberge (PF8 Genotyping of Pathogens and Public Health Platform, Institut Pasteur, Paris) for handling the MLST database. This study was partly supported by Valio Ltd (Helsinki, Finland) and Tekes (the Finnish Funding Agency for Technology and Innovation). 


\section{References}

Anastasiou, R., Leverrier, P., Krestas, I., Rouault, A., Kalantzopoulos, G., Boyaval, P. Tsakalidou, E., Jan, G., 2006. Changes in protein synthesis during thermal adaptation of Propionibacterium freudenreichii subsp. shermanii. International Journal of Food Microbiology 108, 301-314.

Bilhere, E., Lucas, P.M., Claisse, O., Lonvaud-Funel, A., 2009. Multilocus sequence typing of Oenococcus oeni: detection of two subpopulations shaped by intergenic recombination. Applied and Environmental Microbiology 75, 1291-1300.

Cai, H., Rodriguez, B.T., Zhang, W., Broadbent, J.R., Steele, J.L., 2007. Genotypic and phenotypic characterization of Lactobacillus casei strains isolated from different ecological niches suggests frequent recombination and niche specificity. Microbiology 153, 2655-2665.

Cousin, F.J., Matter, D.D., Foligné, B., Jan, G., 2010. Dairy propionibacteria as human probiotics: a review of recent evidence. Dairy Science and Technology. doi:10.1051/ dst/2010032.

Cummins, C.S., Johnson, J.L., 1986. Genus I. Propionibacterium Orla-Jensen 1909. In: Sneath, P.H.A., Mair, N.S., Sharpe, M.E., Holt, J.G. (Eds.), Bergey's Manual of Systematic Bacteriology. Williams \& Wilkins, Baltimore, pp. 1346-1353.

Dasen, G., Smutny, J., Teuber, M., Meile, L., 1998. Classification and identification of propionibacteria based on ribosomal RNA genes and PCR. Systematic and Applied Microbiology 21, 251-259.

de Carvalho, A.F., Gautier, M., Grimont, F., 1994. Identification of dairy Propionibacterium species by rRNA gene restriction patterns. Research in Microbiology 145, 667-676.

de las Rivas, B., Marcobal, A., Munoz, R., 2004. Allelic diversity and population structure in Oenococcus oeni as determined from sequence analysis of housekeeping genes. Applied and Environmental Microbiology 70, 7210-7219.

de las Rivas, B., Marcobal, A., Munoz, R., 2006. Development of a multilocus sequence typing method for analysis of Lactobacillus plantarum strains. Microbiology 152 , 85-93.

Delorme, C., Bartholini, C., Bolotine, A., Ehrlich, S.D., Renault, P., 2010. Emergence of a cell wall protease in the Streptococcus thermophilus population. Applied and Environmental Microbiology 76, 451-460.

Deutsch, S.M., Falentin, H., Dols-Lafargue, M., Lapointe, G., Roy, D., 2008. Capsular exopolysaccharide biosynthesis gene of Propionibacterium freudenreichii subsp. shermanii. International Journal of Food Microbiology 125, 252-258.

Dherbécourt, J., Maillard, M.B., Catheline, D., Thierry, A., 2008. Production of branchedchain aroma compounds by Propionibacterium freudenreichii: links with the biosynthesis of membrane fatty acids. Journal of Applied Microbiology 105, 977-985.

Dherbécourt, J., Falentin, H., Jardin, J., Maillard, M.B., Baglinière, F., Barloy-Hubler, F., Thierry, A., 2010. Identification of a secreted lipolytic esterase in Propionibacterium freudenreichii, a ripening process bacterium involved in Emmental cheese lipolysis. Applied and Environmental Microbiology 76, 1181-1188.

Didelot, X., Falush, D., 2007. Inference of bacterial microevolution using multilocus sequence data. Genetics 175, 1251-1266.

Falentin, H., Deutsch, S.M., Jan, G., Loux, V., Thierry, A., Parayre, S., Maillard, M.B., Dherbécourt, J., Cousin, F.J., Jardin, J., Siguier, P., Couloux, A., Barbe, V., Vacherie, B. Wincker, P., Gibrat, J.F., Gaillardin, C., Lortal, S., 2010. The complete genome of Propionibacterium freudenreichii CIRM-BIA1 ${ }^{\mathrm{T}}$, a hardy Actinobacterium with food and probiotic applications. PLOS ONE 5, e11748.

Fessler, D., Casey, M.G., Puhan, Z., 1999. Propionibacteria flora in Swiss raw milk from lowlands and alps. Lait 79, 201-209.

Gautier, M., de Carvalho, A.F., Rouault, A., 1996. DNA fingerprinting of dairy propionibacteria strains by pulsed-field gel electrophoresis. Current Microbiology $32,17-24$.

Guttman, D.S., Dykhuizen, D.E., 1994. Clonal divergence in Escherichia coli as a result of recombination, not mutation. Science $1380-1383$.

Hanage, W.P., Fraser, C., Spratt, B.G., 2005. Fuzzy species among recombinogenic bacteria. BMC Biology 6.

Hudson, R.R., Kaplan, N.L., 1985. Statistical properties of the number of recombination events in the history of a sample of DNA sequences. Genetics 111, 147-164.

Jan, G., Lan, A., Leverrier, P., 2007. Dairy propionibacteria as probiotics. In: Saarela, M. (Ed.), Functionnal Dairy Products. Cambridge, pp. 165-194.

Jolley, K.A., Chan, M.S., Maiden, M.C., 2004. mlstdbNet - distributed multi-locus sequence typing (MLST) databases. BMC Bioinformatics 5, 86.

Lan, A., Bruneau, A., Philippe, C., Rochet, V., Rouault, A., Herve, C., Roland, N., Rabot, S., Jan, G., 2007. Survival and metabolic activity of selected strains of Propionibacterium freudenreichii in the gastrointestinal tract of human microbiota-associated rats. British Journal of Nutrition 97, 714-724.

Langsrud, T., Reinbold, G.W., 1973. Flavor development and microbiology of Swiss cheese - a review. III. Ripening and flavor production. Journal of Milk and Food Technology 36, 593-609.

Lemée, R., Lortal, S., Van Heijenoort, J., 1995. Autolysis of dairy propionibacteria: isolation and renaturing gel electrophoresis of the autolysins of Propionibacterium freudenreichii CNRZ 725. Lait 75, 345-365.

Maiden, M.C., 2006. Multilocus sequence typing of bacteria. Annual Review of Microbiology 60, 561-588

Maiden, M.C., Bygraves, J.A., Feil, E., Morelli, G., Russell, J.E., Urwin, R., Zhang, Q., Zhou, J. Zurth, K., Caugant, D.A., Feavers, I.M., Achtman, M., Spratt, B.G., 1998. Multilocus sequence typing: a portable approach to the identification of clones within populations of pathogenic microorganisms. Proceedings of the National Academy of Sciences of the United States of America 95, 3140-3145.

Malik, A.C., Reinbold, G.W., Vedamuthu, E.R., 1968. An evaluation of the taxonomy of Propionibacterium. Canadian Journal of Microbiology 14, 1185-1191.

Maynard Smith, J., Smith, N.H., 1998. Detecting recombination from gene trees. Molecular Biology and Evolution 15, 590-599.

Moore, W.E.C., Holdeman, L.V., 1974. Propionibacterium. In: Buchanan, R.E., Gibbons, R.E (Eds.), Bergey's Manual of Determinative Bacteriology. Baltimore, pp. 633-641.

Nicolas, P., Mondot, S., Achaz, G., Bouchenot, C., Bernardet, J.F., Duchaud, E., 2008 Population structure of the fish-pathogenic bacterium Flavobacterium psychrophilum. Applied and Environmental Microbiology 74, 3702-3709.

Perez-Losada, M., Browne, E.B., Madsen, A., Wirth, T., Viscidi, R.P., Crandall, K.A., 2006. Population genetics of microbial pathogens estimated from multilocus sequence typing (MLST) data. Infection, Genetics and Evolution 6, 97-112.

Petersen, A., Christensen, H., Kodjo, A., Weiser, G.C., Bisgaard, M., 2009. Development of a multilocus sequence typing (MLST) scheme for Mannheimia haemolytica and assessment of the population structure of isolates obtained from cattle and sheep. Infection, Genetics and Evolution 9, 626-632.

Rademaker, J.L., Herbet, H., Starrenburg, M.J., Naser, S.M., Gevers, D., Kelly, W.J. Hugenholtz, J., Swings, J., van Hylckama Vlieg, J.E.T., 2007. Diversity analysis of dairy and nondairy Lactococcus lactis isolates, using a novel multilocus sequence analysis scheme and (GTG)5-PCR fingerprinting. Applied and Environmental Microbiology 73, 7128-7137.

Rehberger, T.G., 1993. Genome analysis of Propionibacterium freudenreichii by pulsedfield gel electrophoresis. Current Microbiology 27, 21-25.

Rehberger, T.G., Glatz, B.A., 1990. Characterization of Propionibacterium plasmids. Applied and Environmental Microbiology 56, 864-871.

Rossi, F., Torriani, S., Dellaglio, F., 1998. Identification and clustering of dairy propionibacteria by RAPD-PCR and CGE-REA methods. Journal of Applied Microbiology 85, 956-964.

Sakwinska, O., Kuhn, G., Balmelli, C., Francioli, P., Giddey, M., Perreten, V., Riesen, A. Zysset, F., Blanc, D.S., Moreillon, P., 2009. Genetic diversity and ecological success of Staphylococcus aureus strains colonizing humans. Applied and Environmental Microbiology 75, 175-183.

Staley, J.T., Krieg, N.R., 1984. Classification of procaryotic organisms: an overview. In Krieg, N.R., Holt, J.G. (Eds.), Bergey's Manual of Determinative Bacteriology. Baltimore, pp. 1-4.

Thierry, A., Maillard, M.B., Yvon, M., 2002. Conversion of L-leucine to isovaleric acid by Propionibacterium freudenreichii TL 34 and ITGP23. Applied and Environmental Microbiology 68, 608-615.

Thierry, A., Maillard, M.B., Richoux, R., Kerjean, J.R., Lortal, S., 2005. Propionibacterium freudenreichii strains quantitatively affect production of volatile compounds in Swiss cheese. Lait 85, 57-74.

Tilsala-Timisjarvi, A, Alatossava, T. 2001. Characterization of the $16 \mathrm{~S}-23 \mathrm{~S}$ and $23 \mathrm{~S}$ $5 \mathrm{~S}$ rRNA intergenic spacer regions of dairy propionibacteria and their identification with species-specific primers by PCR. International Journal of Food Microbiology $68,45-52$.

Untergasser, A., Nijveen, H., Rao, X., Bisseling, T., Geurts, R., Leunissen, J.A., 2007. Primer3Plus, an enhanced web interface to Primer3. Nucleic Acids Research 35, W71-W74.

Vorobjeva, L.I., 1999. The genus Propionibacterium. In: Vorobjeva, L.I. (Ed.), Propionibacteria. Kluwer Academic, Boston, pp. 4-46.

Vos, M., Didelot, X., 2009. A comparison of homologous recombination rates in bacteria and archaea. ISME Journal 3, 199-208.

Watterson, G.A., 1978. The homogosity test of neutrality. Genetics 88, 405-417. 